\title{
INVENTARISASI TUMBUHAN PENGHASIL PEWARNA ALAMI DI KEBUN RAYA CIBODAS
}

\author{
Muhammad Efendi ${ }^{1}$, Intan Gresia Hapitasari ${ }^{2)}$, Rustandi ${ }^{1)}$, Ateng Supriyatna ${ }^{2)}$ \\ ${ }^{1}$ UPT BKT Kebun Raya Cibodas - Lembaga Ilmu Pengetahuan Indonesia \\ J1. Kebun Raya Cibodas, Sindanglaya Cipanas, Cianjur, Jawa Barat \\ 2) Jurusan Biologi, Fakultas Sains dan Teknologi, \\ UIN Sunan Gunung Djati, Bandung \\ Email : muhammadefendi05@gmail.com ; intangresia@gmail.com ; rustandi@lipi.go.id ; \\ ateng.supriatna@yahoo.co.id.
}

\begin{abstract}
Cibodas Botanic Garden, as ex situ conservation areas, preserves living materials of the wet mountains flora. Recently, bioprospecting study for dye in this areas has not yet been done. Therefor, the aim of this study was to inventory of natural dye in Cibodas Botanic Garden. Sampel were collected by exploration methods. Parts of plants, kinds of color and its chemical compound were recorded based on observation, interview with nurseries and literature study. A total of 122 species that belongs to 57 families were potentially source as natural dye, 23 of them has been traditionally used as natural dye in the various places in Indonesia. The plant family of Fabaceae, Rosaceae, Symplocaceae, and Myrtaceae are the most families that used as a source of dye. The color can be produce are ranging from red, purple, yellow, black, brown, green, blue, and orange. The plant organs used as a source of dye are roots, stems, leaves, flowers, and fruit. Begonia semperflorens, Berberis nepaulensis, $B$. fortunei, Symplocosspp., Liquidambar formosana, andDiospyros kaki were potentially for natural dye, as reported from other countries.
\end{abstract}

Keywords: inventory, Cibodas Botanic Garden, natural dye, remnant forest

\section{Pendahuluan}

Tumbuhan secara alami mengandung pigmen warna yang khas sehingga dapat dimanfaatkan sebagai pewarna alami. Setidaknya lebih dari 100 jenis tumbuhan pewarna asli Indonesia telah dimanfaatkan sebagai pewarna kain, makanan, kerajinan, anyaman maupun sebagai kosmetik, pewarna alat tradisional dan bahan cat perahu oleh masyarakat pedalaman (Heyne, 1987 ; Harbelubun et al., 2005; Setyowati et al., 2005 ; Sutara, 2009 ; Rini et al., 2011; Muzzayinah, 2012 ; Rosyida dan Zulfiya, 2013).

Kandungan pewarna yang rendah, waktu pencelupan relatif lebih lama dan rumit serta bahan yang sulit didapatkan menyebabkan pewarna alami kurang diminati sehingga masyarakat beralih pada pewarna sintetis (Vankar, 2000). Di sisi lain, penggunaan pewarna sintetis dapat menyebabkan alergi, karsinogenik, mengganggu kesehatan, dan dapat mencemari lingkungan, bahkan di beberapa negara maju pewarna sintetis dilarang (Siva, 2007). Untuk menambah pilihan jenis tumbuhan penghasil pewarna alami, maka perlu dilakukan inventarisasi jenis tumbuhan penghasil pewarna dari berbagai kawasan, salah satunya di Kebun Raya Cibodas (KRC).

Kebun Raya Cibodas, sebagai kawasan konservasi ex situ, menyimpan keanekaragaman jenis tumbuhan Indonesia terutama dataran tinggi basah dan hasil pertukaran koleksi dengan negara lain seperti Brazil, Australia, China dan Jepang. Kebun Raya Cibodas terletak di kaki Gunung Gede Pangrango pada ketinggian 1.300 sampai $1.425 \mathrm{~m} \mathrm{dpl}$ dengan luas mencapai 84,89 ha. Total koleksi mencapai 7.000 spesimen terdiri atas 1.198 berbiji dan 72 jenis tumbuhan paku (Widyatmoko et al., 2010). Beberapa bagian dari KRC merupakan remnant forest 
dengan karakteristik vegetasi mirip dengan Taman Nasional Gunung Gede Pangrango (Mutaqien dan Zuhri, 2013).

Kajian bioprospeksi dan pemanfaatan tumbuhan koleksi di KRC telah banyak diungkap, di antaranya sebagai tanaman hias (Rahman dan Juairiah, 2013), bioherbisida (Ismaini, 2015 ; Ismaini dan Lestari, 2015) dan tanaman obat (Gumilang et al., 2005 ; Handayani, 2015). Namun, potensi sebagai tumbuhan pewarna belum pernah dilaporkan. Penelitian ini bertujuan menginventarisasi jenis tumbuhan yang berpotensi sebagai pewarna di KRC dan kawasan remnant forest.

\section{Metodologi}

\subsection{Waktu dan tempat}

Penelitian ini dilaksanakan dari Bulan Agustus hingga Desember 2015 di UPT Balai Konservasi Kebun Raya Cibodas, ditambah dengan empat kawasan remnant forest KRC meliputi Hutan Lumut, Hutan Wornojiwo, Hutan Jalan Akar dan Hutan Kompos. Identifikasi jenis tumbuhan dilakukan di Herbarium KRC.

\subsection{Teknik pengumpulan data}

Bahan yang digunakan dalam penelitian ini merupakan jenis tumbuhan koleksi KRC dan tumbuhan liar di kawasan remnant forest. Pengambilan sampel dilakukan dengan metode eksplorasi, yakni menjelajahi setiap sudut di kawasan koleksi dan empat kawasan remnant forest. Jenis tumbuhan yang menghasilkan warna yang telah diketahui nama ilmiahnya dicatat, sedangkan jenis yang yang belum teridentifikasi dijadikan spesimen herbarium untuk diidentifikasi. Pembuatan spesimen herbarium mengacu pada Rugayah et al. (2004). Penentuan jenis tumbuhan yang penghasil pewarna didasarkan pada penampakan morfologi tumbuhan, pengetahuan perawat koleksi, pengawas koleksi dan pustaka acuan, yaitu Heyne (1987), Lemmens dan Wulijarni-Soetjipto (1992), Harbelubun et al. (2005), Sutara (2009), Rini et al. (2011), Muzzayinah (2012) serta Rosyida dan Zulfiya (2013). Parameter pengamatan meliputi nama jenis tumbuhan, nama lokal, bagian yang dapat menghasilkan pewarna, warna yang dihasilkan, habitus dan persebarannya. Kandungan senyawa kimia dari warna yang dihasilkan didasarkan studi pustaka.
Jenis-jenis tumbuhan yang berpotensi menghasilkan warna selanjutnya diuji tingkat kandungan warna yang dihasilkan dengan metode perebusan. Sebanyak $100 \mathrm{~g}$ sampel dihaluskan direbus dalam sebanyak $500 \mathrm{ml}$ air hingga air air berubah. Selanjutnya, air hasil perebusan diteteskan pada kertas HVS putih dengan pipet. Warna yang tampak pada kertas HVS diukur dengan kertas warna untuk mengetahui jenis warna yang dihasilkan. Tingkat kandungan warna yang dihasilkan selanjutnya dilakukan scoring, dengan kriteria $1=$ sangat kurang, $2=$ =kurang, $3=$ sedang, $4=$ kuat, dan $5=$ sangat kuat.

\subsection{Analisis data}

Data yang sudah diperoleh selanjutnya dianalisis secara deskriptif kualitatif dan diklasifikasikan berdasarkan taksa, jenis warna yang dihasilkan, bagian yang menghasilkan warna dan tingkat kandungan warna yang dihasilkan.

\section{Hasil dan Pembahasan}

\subsection{Jenis Tumbuhan Penghasil Warna di KRC}

Sebanyak 122 jenis dalam 57 suku tumbuhan dicatat sebagai penghasil pewarna, termasuk jenis liar yang ditemukan di kawasan remnant forest KRC (lampiran 1). Dua puluh tiga jenis dari koleksi KRC tersebut telah dimanfaatkan sebagai pewarna, baik sebagai pewarna utama, pewarna campuran maupun pengikat warna, seperti yang pernah dilaporkan oleh peneliti sebelumnya pada masyarakat lokal di Indonesia (Heyne, 1987; Harbelubun et al., 2005; Setyowati et al., 2005; Sutara, 2009; Rini et al., 2011; Muzzayinah, 2012; Rosyida dan Zulfiya, 2013). Fabaceae memiliki anggota jenis tumbuhan berpotensi pewarna terbanyak dibandingkan dengan suku yang lain. Suku Fabaceae tergolong suku yang besar dan banyak dikoleksi di KRC, begitu juga dengan Myrtaceae dan Rosaceae.Beberapa suku yang memiliki jumlah jenis berpotensi pewarna tersaji Gambar 1

Artocarpus heterophyllus, Caesalpinia sappan, Dahlia sp., Bixa orellana, Ardisia spp., Bauhinia variegata dan jenis Indigofera spp. telah dimanfaatkan sebagai pewarna oleh masyarakat lokal Indonesia. Jenis-jenis tersebut juga telah dikembangkan sebagai pewarna kain di India, Birma, Srilanka, dan Nepal (Cristea and Vilarem, 2005; Siva, 


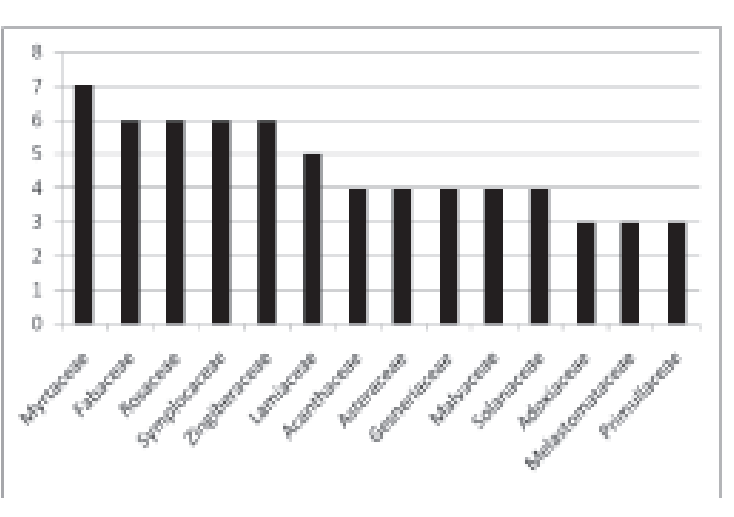

Gambar 1.

Persebaran jumlah jenis tumbuhan beberapa suku penghasil warna di Kebun Raya Cibodas

2007; Saxena and Raja,2013). Castanopsis spp. (Fagaceae) dengan kandungan tanin tinggi sehingga dapat dikembangkan sebagai pewarna alam (Heyne, 1987).

Jenis tumbuhan pewarna tidak hanya berasal dari Indonesia. Beberapa jenis tumbuhan pewarna koleksi KRC berasal dari luar negeri antara lain Iresine herbstii, Prunus spp., Berberis spp., Dahlia sp., Bouganvillea, termasuk jenis invasif di kawasan remnant forest yaitu Dichroa febrifuga, Clidemia hirta, Piper aduncum dan Strobilanthes hamiltoniana. Di Pakistan, Iresine herbstii dimanfaatkan sebagai pewarna kain dan makanan (Batool et al., 2013). Begitu juga dengan jenis Prunus spp. dijadikan sebagai pewarna kosmetik (SequenFrey, 1981). Liquidambar formosana dan Diospyros kaki telah dimanfaatkan sebagai pewarna alami oleh masyarakat China (Liu et al., 2014). Berberis nepaulensis dan B. fortunei yang didatangkan dari Nepal, berpotensi sebagai pewarna seperti halnya pada $B$. aristata yang telah dimanfaatkan sebagai sumber warna di India (Semwal et al., 2012).

\subsection{Keanekaragaman Warna yang Dihasilkan}

Keanekaragaman jenis tumbuhan berdasarkan warna yang dihasilkan dapat dikelompokkan menjadi penghasil warna merah, kuning, biru, ungu, hijau, coklat dan hitam. Coklat merupakan jenis warna paling banyak dihasilkan dari jenis tumbuhan, yakni sebanyak 31 jenis, sedangkan biru hanya dihasilkan dari empat jenis tumbuhan saja (Gambar 2).

Warna merah.Warna merah biasa dihasilkan oleh pigmen karotenoid dan antosianin yang banyak

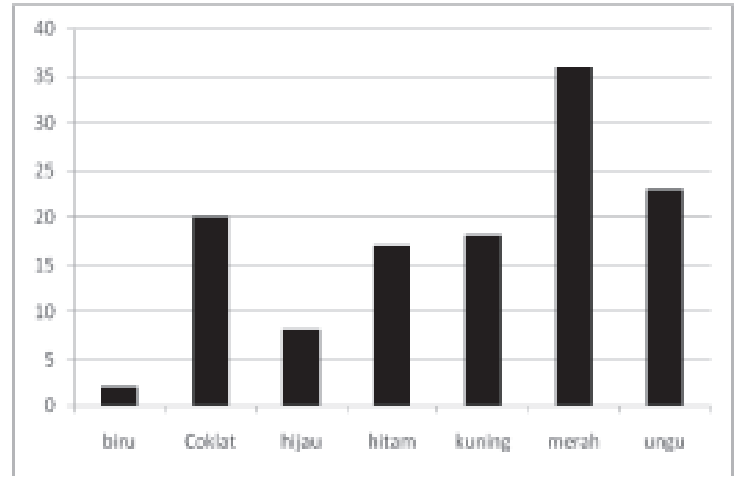

Gambar 2.

Jumlah tumbuhan berdasarkan warna yang dihasilkan

ditemukan pada bagian akar, batang, bunga, buah dan jarang ditemukan di daun.Selain itu, senyawa bixinpada jenis Bixa orellana dan sappanin pada C. sappansebagai sumber warna merah (Lemmans dan Soetjipto, 1992). Beberapa jenis tumbuhan yang sumber warna merah antara lain Caesalpinia sappan (batang), Berberis nepaulensis (akar dan batang), Homalomena pendula (getah), Ziziphus sp. (batang), Pterocarpus indicus (batang), Phyllanthus emblica (batang), Syzygium zeylanicum (batang), dan Hibiscus rosa-sinensis (kelompak bunga).

Warna kuning.Warna kuning dihasilkan oleh pigmen karotenoid dan curcumin (Lemmans dan Soetjipto, 1992; Siva, 2007) dan berberin (Saxena and Raja, 2014). Sumber utama warna kuning yang dapat ditemukan di KRC antara lain rimpang Curcuma longa, C. mangga, C. xanthorriza, dan Zingiber casumounar yang telah dikenal sebagai pewarna makanan. Untuk menghasilkan warna kuning, rimpang diparut, ditambahkan sedikit air kemudian diperas dan diambil airnya.Setelah itu, pewarna tersebut ditambahkan pada adonan makanan.Untuk mendapatkan warna kuning yang lebih mencolok, ditambahkan sirih sehingga warna yang lebih kuat (Heyne 1987).Rendaman kayu nangka juga dapat dimanfaatkan sebagai sumber warna kuning pada batik (Rosyida dan Zulfiya, 2013).Berberis fortunei berpotensi sebagai pewarna kuning.

Warna biru. Warna biru banyak dihasilkan dari tanaman Indigofera dengan pigmen indigotina (Siva, 2007), salah satunya Indigofera scandens yang merupakan koleksi di KRC.Begitu juga dengan buah 
Dichroa febrifuga dan bunga Lavandula officinalis L. berpotensi sebagai sumber warna biru.

Warna ungu. Warna ungu dihasilkan dari senyawa antosianin (Lemmens dan WulijarniSoetjipto, 1992). Beberapa jenis dengan kandungan warna ungu antara lain Clidemia hirta (bunga dan buah), Dianella javanica (buah), Didymocarpus asperifolia (bunga), Melastoma malabathricum (bunga dan buah), Muchlenbackia platyclades (buah), Peristrophe hyssopifolia (bunga), Strobilanthes cernua (daun) dan Symplocos spp. (buah).

Warna hijau. Warna hijau biasanya diperoleh dari pigmen klorofil yang digunakan sebagai pewarna makanan dan minuman (Siva, 2007). Beberapa jenis tumbuhan sebagai penghasil warna hijau antara lain Dichroa febrifuga, Foeniculum vulgare, Mentha arvensis, Pandanus amaryllifolius, Piper aduncum, Sophora tomentosa dan Camelia sinensis. Jenis lain yang berpotensi sebagai sumber warna hijau adalah Aristea ecklonii, Lavandula officinallis, Balsamina impatiens dan B. platypethala.

Warna coklat. Tanin merupakan pigmen yang menghasilkan warna coklat hingga kehitaman (Siva, 2007). Sumber warna coklat yang dapat ditemukan di KRC yaitu Camelia sinensis, Canna indica, Heliconia colinsiana, Magnolia montana, Musa sp., Trema orientale dan Odontosoria chinensis.

Warna hitam. Warna hitam banyak diperoleh dari kulit batang dan buah. Beberapa jenis buah memiliki kulit buah berwarna hitam seperti Ardisia pardalina, A. fuliginosa, Ricinus communis dan Macropanax undulatus sehingga dalam jumlah banyak dapat dijadikan sebagai pewarna hitam. Rendaman kulit kayu Caesalpinia sappan dan Rhodomyrtus tomentosa direndam dalam lumpur dapat menghasilkan warna hitam kelam (Heyne, 1987).

\subsection{Bagian tumbuhan penghasil warna}

Warna dapat diekstrak dari bagian akar, umbi, batang, daun, bunga, buah termasuk biji,serta getah. Bunga merupakan bagian tumbuhan yang paling banyak dimanfaatkan sebagai pewarna karena karakteristik warna yang bervariasi dan mudah diamati.Beberapa jenis tumbuhan menghasilkan bunga sepanjang tahun sehingga mudah didapatkan, sedangkan umbi, akar dan batang sulit diidentifikasi potensi pigmen warna.Persebaran jumlah tumbuhan potensi warna berdasarkan bagian yang dimanfaatkan sebagai pewarna disajikan dalam Gambar 3 .

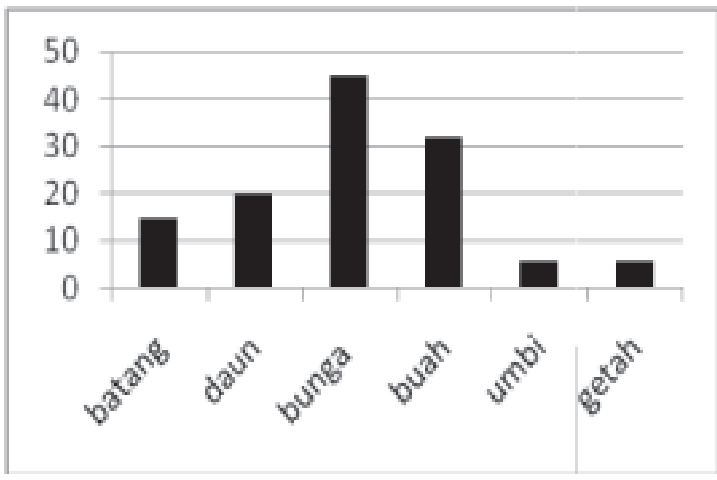

Gambar 3.

Jumlah tumbuhan berdasarkan bagian yang dimanfaatkan

Akar dan batang. Akar, batang dan kulit kayu memiliki kandungan tannin tinggi sehingga dapat dimanfaatkan sebagai pewarna. Akar dan batang dari Castanopsisspp., Trema orientale, Caesalpinia sappan, Pterocarpus indicus, Phyllanthus emblica, Macaranga sp., Syzygium polyanthum dan Rhodomyrtus tomentosa telah dimanfaatkan sebagai pewarna, terutama warna coklat, hitam atau merah, sedangkan batang Artocarpus heterophyllus sebagai sumber warna kuning.

Daun. Daun segar kurang memberikan variasi warna. Kandungan utama berupa klorofil memberikan warna hijau makanan antara lain Dracaenaangustifolia digunakan sebagai pewarna cendol dan Camelia chinensis yang telah dikeringkan dan hasil fermentasinya digunakan dalam pewarna minuman.de Winter dan Amoroso (2003) melaporkan bahwa daun Odontosoria chinensis yang dikeringkan menjadi sumber pewarna coklat.

Bunga. Warna yang mencolok serta bentuk beragam menjadikan bunga lebih mudah dikenali sebagai sumber pewarna dibanding batang dan akar. Jenis warna yang dihasilkan antara lain merah, ungu, kuning,biru dan jingga. Selain itu, beberapa jenis mampu berbunga sepanjang tahun sehingga menjamin ketersediaannya di alam. Beberapa jenis yang berpotensi warna pada bagian bunga antara lain Rhododendron spp., Salvia spp., Camelia spp., Prunus spp., Hisbiscus rosa-chinensis, Peristrophe sp. dan Dahlia pinnata. 
Buah dan biji. Buah dan biji merupakan sumber warna yang juga dapat ditemukan pada tumbuhan. Warna yang menempel di telapak tangan saat proses pengupasan buah mengindikasikan tingkat kepekatan dan jenis warna. Salah satunya Pittosporum sp., memberikan warna hitam saat proses pengupasan. Begitu juga dengan Acmena acuminatissima (kupai landak) menyisakan warna merah-kehitaman saat dikupas. Beberapa jenis tumbuhan liar memiliki warna buah yang pekat, seperti yang ditemukan pada Vaccinium spp., Symplocos spp., Melastoma malabathricum, Dianella javanica, Berberis spp., dan Clidemia hirta berpotensi menghasilkan warna alami.

\subsection{Tingkat kepekatan warna yang dihasilkan}

Dari 100 sampel yang diuji, 44 jenis tumbuhan memiliki tingkat kandungan warna sedang hingga sangat kuat (gambar 4).Begonia semperflorens, Bidens pilosa, Berberisnepaulensis, Muehlenbeckia platyclados, Calliandra haematocephala, Callistemon citrinus, Curcuma domestica, Dianella javanica, Indigofera scandens, dan Strobilanthes cernua memiliki kandungan warna yang kuat sehingga berpotensi untuk dikembangkan sebagai pewarna.

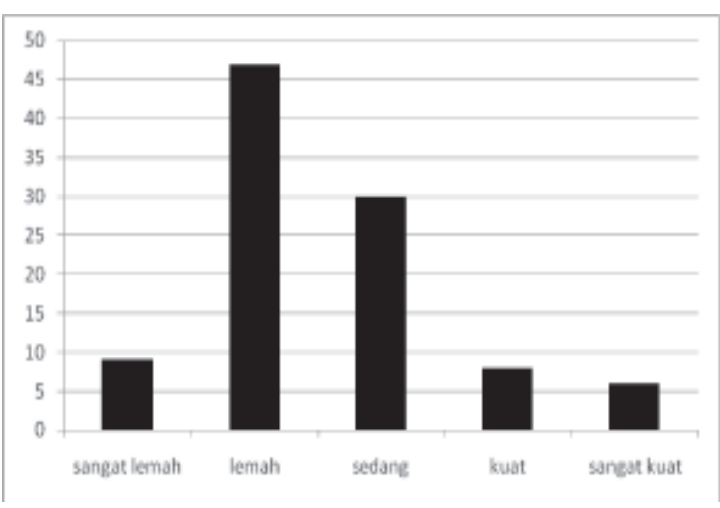

Gambar 4.

Jumlah tumbuhan berdasarkan tingkat kandungan warna yang dihasilkan

Sampai saat ini, senyawa kimia dari tumbuhan penghasil warna di KRC belum banyak diketahui.Ke depannya penelitian tentang kandungan senyawa kimia perlu dilakukan untuk mendapatkan jenisdapat dikembangkan menjadi pewarna alami.

\section{Simpulan dan Saran}

Berdasarkan 122 jenis yang diinventarisasi, beberapa jenis tumbuhan koleksi KRC dapat dikembangkan sebagai pewarna alami, terutama jenis tumbuhan yang belum dimanfaatkan oleh masyarakat Indonesia dan jenis tumbuhan yang memiliki kanduangan pewarna yang kuat seperti pada Begonia semperflorens, Berberis nepaulensis, $B$. fortunei, Symplocos spp., Liquidambar formosanadanArdisia spp. Ke depannya uji kandungan senyawa kimia dari warna yang dihasilkan sangat diperlukan sehingga dapat dikembangkan sebagai pewarna alami.

\section{Ucapan Terima Kasih}

Penulis mengucapkan terima kasih kepada Bapak Dr. Andria Agusta dan Bapak Wiguna Rahman, S.P. yang telah memberikan masukan dalam penulisan tulisan ini.Ucapan terima kasih kami ucapkan kepada para perawat koleksi dan pengawas di KRC yang memberikan informasi mengenai tumbuhan pewarna dan membantu dalam pengambilan sampel.

\section{Daftar Pustaka}

Batool, F., S. Adeel, M. Azeem, A.A. Khan and I. Ahmad. 2013. Gamma radiations induced improvement in dyeing properties and colorfastness of cotton fabrics dyed with chicken gizzard leaves extract. Physic and Chemistry,89.33-37.

de Winter, W.P. dan V.B. Amoroso. 2003. Plant Resources of South-east Asia Cryptogams : Ferns and Fern Allies. Prosea foundation, Bogor.

Heyne, K. 1987. Tumbuhan Berguna Indonesia IIV.Sarana Wana Jaya,Jakarta.

Gumilang, A.R, A. Hidayat dan E. Agustini. 2005. Tanaman Berpotensi Obat Kebun Raya Cibodas. UPT Balai Konservasi Tumbuhan Kebun Raya Cibodas-LIPI, Cianjur.

Handayani, A. 2015.Keanekaragaman Lamiaceae berpotensi obat koleksi Taman Tumbuhan Obat Kebun Raya Cibodas, Jawa Barat.Dalam 
Proseding seminar Nasional Masyarakat Biodiversitas Indonesia,1(6).1324-1327.

Harbelubun, A.E., E.M. Kesaulija dan Y.Y. Rahawarin. 2005. Tumbuhan Pewarna Alami dan Pemanfaatannya secara Tradisional oleh Suku Marori Men-Gey di Taman Nasional Wasur Kabupaten Merauke.Biodiversitas6(4).281284.

Lemmens, R.H.M.J. dan W. Wulijarni-Soetjipto (Eds). 1992. Plant Resources of South-East Asia 3. Dye and tannin-producing plants. Prosea foundation, Bogor.

Liu, Y., S. Ahmed, B. Liu, Z. Guo, W. Huang, X. Wu, S. Li, J. Zhou, Q. Lei, dan C. Long. 2014. Ethnobotany of dye plants in Dong communities of China. J. Ethnobiology and Ethnomedicine 10(23). 1-8.

Mutaqien, Z. dan M. Zuhri. 2013. Establishing a longterm permanent plot in remnant forest of Cibodas Botanic Gardens, West Java. Biodiversitas 12.218-224.

Mutaqien, A., V.M. Tresnanovia, dan M. Zuhri. 2011. Penyebaran tumbuhan asing di Hutan Wornojiwo Kebun Raya Cibodas. Conference Paper: tersedia di: https:// www.researchgate.net/publication/256202773 Penyebaran_Jenis_Tumbuhan_Asing_di_Hutan_Womojiwo_ Kebun_Raya_Cibodas_Cianjur_Jawa_Barat. diakses tanggal 4 Februari 2016.

Rahman, W. dan L. Juairiah.Evaluasi Perkembangan dan Pemanfaatan Tanaman Hias.Prosiding ekspose dan seminar pembangunan kebun raya daerah.Bogor, tanggal 25-26 November 2013.
Rini, S., Sugiarti dan M.K. Riswati.2011. Pesona Warna Alami Indonesia. Hanggawarawati, PS., dan D. Sulis (eds). Yayasan Keanekaragaman Indonesia, Jakarta.

Rugayah, Retnowati, A, F.I. Windadri dan A. Hidayat.2004. Pengumpulan Data Taksonomi. Dalam Rugayah, E.A. Widjaja dan Praptiwi (eds). Pedoman Pengumpulan Data Keanekaragaman Flora. Puslit Biologi LIPI, Bogor.

Rosyida, A. dan A. Zulfiya.2013. Pewarnaan Bahan Tekstil dengan Menggunakan Ekstrak Kayu Nangka dan Teknik Pewarnaannya untuk Mendapatkan Hasil yang Optimal.Jurnal Rekayasa Proses 7(2). 52-58.

Setyowati, F.M., S. Riswan dan S. Susiarti. 2005. Etnobotani Masyarakat Dayak Ngaju di Daerah Timpah Kalimantan Tengah. Jurnal Teknologi Lingkungan6(3).502-510.

Siva, R. 2007. Status of Natural Dyes and Dye-yielding Plants in India.Current Science92(27).916-924.

Sutara, P.K. 2009.Jenis tumbuhan sebagai pewarna alam pada beberapa perusahaan tenun di Gianyar.Jurnal Bumi Lestari9(2): 217-223.

Vankar, P.S. 2000.Chemistry of Natural Dyes.Resonance 2000.73-80.

Cristea, D. and G. Vilarem. 2006. Improving light fastness of natural dyes on cotton yarn. Pigment and Dye70.238-245.

Widyatmoko, D., N. Suryana, A. Suhatman dan Rustandi. 2010. List of living plants collection cultivated in Cibodas Botanic Gardens. Indonesian Institute of Sciences, Cibodas Botanic Gardens, Cianjur. 
Lampiran 1. Data jenis tumbuhan potensi pewarna di Kebun Raya Cibodas dan kawasanremnant forest.

\begin{tabular}{|c|c|c|c|c|c|c|c|}
\hline No & Nama Jenis Tumbuhan & Suku & $\begin{array}{c}\text { Bagian } \\
\text { Tumbuhan } \\
\text { yang } \\
\text { Dimanfaakan }\end{array}$ & $\begin{array}{c}\text { Warna } \\
\text { yang } \\
\text { Dihasilkan }\end{array}$ & $\begin{array}{c}\text { Asal } \\
\text { Koleksi } \\
\text { n }\end{array}$ & habitus & $\begin{array}{c}\text { Tingkat } \\
\text { kandu- } \\
\text { ngan }\end{array}$ \\
\hline 1 & Abutilon indicum (L.) Sweet & Malvaceae & bunga & kuning & China & $\mathrm{S}$ & 2 \\
\hline 2 & $\begin{array}{l}\text { Abutilon megapotamicum (Spreng.) } \\
\text { St. Hil. dan Naudin }\end{array}$ & Malvaceae & bunga & merah & China & $\mathrm{S}$ & 2 \\
\hline 3 & $\begin{array}{l}\text { Acmena acuminatissima (Blume) } \\
\text { Merr. dan Perr. }\end{array}$ & Myrtaceae & buah & merah $\mathrm{J}$ & Jambi, Papua & $\mathrm{T}$ & 2 \\
\hline 4 & $\begin{array}{l}\text { Aeschynanthus horsfieldii } \\
(\mathrm{R} . \mathrm{Br}) \text { Kunze }\end{array}$ & Gesneriaceae & bunga & merah & Jawa & $\mathrm{H}$ & 2 \\
\hline 5 & Aeschynanthus radicans Jack. & Gesneriaceae & bunga & merah & Jawa & $\mathrm{H}$ & 2 \\
\hline 6 & Allamanda cathartica L. & Apocynaceae & bunga & kuning & Brazil & W.Cl & 2 \\
\hline 8 & Ardisia fuliginosa Blume & Primullaceae & kulit buah & hitam & Sumatra & $\mathrm{S}$ & 3 \\
\hline 7 & Ardisia pardalina Mez. & Primullaceae & kulit buah & Coklat & Sumatra & $\mathrm{S}$ & 3 \\
\hline 9 & Ardisia villosa Roxb. & Primullaceae & kulit buah & ungu & China, Jawa & $\mathrm{S}$ & 3 \\
\hline 10 & Arisaema filiforme (Blume) Reinw. & Araceae & buah & kuning & Jawa & P.H & 2 \\
\hline 11 & Aristea ecklonii Backer & Iridaceae & bunga & biru Aus & stralia, S. Afrika & $\mathrm{a} \quad \mathrm{P}$ & 2 \\
\hline 12 & Artocarpus heterophyllus L. & Moraceae & batang & coklat & Jawa & $\mathrm{T}$ & 3 \\
\hline 13 & Asclepias curassivica $\mathrm{L}$. & Asclepiadaceae & bunga & kuning & Perancis & $\mathrm{S}$ & 2 \\
\hline 14 & Bauhinia variegata $\mathrm{L}$. & Fabaceae & bunga & ungu & Burma, India & $\mathrm{T}$ & 2 \\
\hline 15 & $\begin{array}{l}\text { Begonia semperflorens Link } \\
\text { dan Otto. }\end{array}$ & Begoniaceae & bunga, daun & merah & Brazil & $\mathrm{H}$ & 5 \\
\hline 16 & Berberis fortunei Lindl. & Berberidaceae & batang & kuning & China & $\mathrm{S}$ & 2 \\
\hline 17 & Berberis nepaulensis (DC.) Spreng. & Berberidaceae & buah & merah & $\begin{array}{c}\text { SE Asia - } \\
\text { Formosana }\end{array}$ & $\mathrm{S}$ & 5 \\
\hline 18 & Bidens pilosa $\mathrm{L}$. & Asteraceae dau & an, bunga, batang & kuning & - & $\mathrm{H}$ & 4 \\
\hline 19 & Bixa orellana $\mathrm{L}$. & Bixaceae & biji & merah jingga & a Australia & $\mathrm{S}$ & - \\
\hline 20 & $\begin{array}{l}\text { Bougainvillea glabra Choisy } \\
\text { forma sanderiana (Bailey) } \\
\text { O. Deg. dan I. Deg. }\end{array}$ & Nyctaginaceae & bunga & ungu & Brazil & W.Cl & 3 \\
\hline 21 & Caesalpinia sappan L. & Fabaceae & kulit batang & merah & Aceh & $\mathrm{S} / \mathrm{T}$ & - \\
\hline 22 & Calliandra haematocephala Hassk. & F. Fabaceae & bunga & merah An & merika Selatan & $\mathrm{S}$ & 4 \\
\hline 23 & Callistemon citrinus Skeels. & Myrtaceae & bunga & merah & Australia & $\mathrm{S} / \mathrm{T}$ & 4 \\
\hline 24 & Camellia japonica L. & Theaceae & bunga & ungu & Jepang & $\mathrm{S}$ & 5 \\
\hline 25 & Camellia sinensis (L) Kuntze & Theaceae & daun & hijau & Jepang & $\mathrm{S}$ & 3 \\
\hline 26 & Campanula latilobaA. DC & Campanulaceae & bunga & coklat & Siberia & P.H & 4 \\
\hline 27 & Canna indica $\mathrm{L}$. & Cannacaceae & bunga & coklat An & merika Selatan & $\mathrm{H}$ & 4 \\
\hline 28 & Castanopsis argentea A. DC & Fagaceae & kulit batang & Coklat & Jawa & $\mathrm{T}$ & 4 \\
\hline 29 & Castanopsis javanica A.DC & Fagaceae & kulit batang & Coklat $\mathrm{Ja}$ & Jawa, Sumatra & $\mathrm{T}$ & 3 \\
\hline 30 & Casuarina equisetifolia L. & Casuarinaceae & batang & merah & Australia & $\mathrm{T}$ & 3 \\
\hline 31 & Casuarina rigida $\mathrm{L}$. & Casuarinaceae & batang & coklat & Australia & $\mathrm{T}$ & 2 \\
\hline 32 & Cestrum diurnum $\mathrm{L}$. & Solanaceae & bunga & kuning & India & $\mathrm{S}$ & 2 \\
\hline 33 & Cestrum purpureum (Lindl.) Standl. & 1. Solanaceae & bunga & merah, ungu & a Meksiko & $\mathrm{S}$ & 2 \\
\hline 34 & Cinnamomum burmanii (Ness.) Blu & umeLauraceae & buah, daun & hitam & Jawa & $\mathrm{T}$ & 3 \\
\hline 35 & Clidemia hirta (L.) D. Don. & Melastomataceae & buah & ungu & - & $\mathrm{S}$ & 2 \\
\hline 36 & Clivia miniata (Lindl.) Bosse & Amaryllidaceae & getah & coklat A & Afrika Selatan & P.H & 3 \\
\hline 37 & Coleus sp. & Lamiaceae & daun & ungu & Afrika & P.H & 2 \\
\hline 38 & Commelina paludosa Bulme & Commelinaceae & buah & jingga & Jawa & P.H & 2 \\
\hline 39 & Cuphea ignea A. DC. & Lythraceae & bunga & merah & Meksiko & $\mathrm{P}$ & 2 \\
\hline 40 & Curcuma aeruginosa Roxb. & Zingiberaceae & umbi & hitam & Jawa & $\mathrm{P}$ & 1 \\
\hline 41 & Curcuma domestica L. & Zingiberaceae & umbi & Kuning & Jawa & $\mathrm{P}$ & 5 \\
\hline 42 & Curcuma longa $\mathrm{L}$. & Zingiberaceae & umbi & kuning & Jawa & $\mathrm{P}$ & 2 \\
\hline 43 & Curcuma mangga Val. & Zingiberaceae & umbi & kuning & Jawa & $\mathrm{P}$ & 1 \\
\hline 44 & Curcuma xanthorriza Roxb. & Zingiberaceae & umbi & kuning & Jawa & $\mathrm{P}$ & 2 \\
\hline 45 & Cyphomandra betaceae Sendtn. & Solanaceae & buah & merah & - & $\mathrm{S}$ & 3 \\
\hline 46 & Dahlia pinnata Cav. & Asteraceae & bunga & merah & - & P.H & 3 \\
\hline 47 & Dianella javanica (Blume) Kunth & Liliaceae & buah & ungu & Jawa & P.H & 4 \\
\hline
\end{tabular}




\begin{tabular}{|c|c|c|c|c|c|c|}
\hline Dichroa febrifuga Lour. & Hidrangeaceae & daun, buah & hijau & Himalaya & P.H & 3 \\
\hline $\begin{array}{l}\text { Didymocarpus asperifolia } \\
\text { (Blume) Bakh. F. }\end{array}$ & Gesneriaceae & bunga & ungu & Jawa & $\mathrm{H}$ & 3 \\
\hline Diospyros kaki L.f. & Ebenaceae & Batang & merahChin & ina dan Jepang & $\mathrm{T}$ & - \\
\hline Elaeocarpus angustifolia Blume & Elaeocarpaceae & buah & ungu & Sumatra & $\mathrm{T}$ & 2 \\
\hline Elaeocarpus grandiflorus Sm. & Elaeocarpaceae & buah & ungu & Jawa & $\mathrm{T}$ & 2 \\
\hline Heliconia colinsiana $\mathrm{L}$. & Heliconiaceae & batang & coklat & Malaya & P.H & 2 \\
\hline Hemerocallis minor Mill. & Liliaceae & bunga & coklat & Asia Timur & P.H & 2 \\
\hline $\begin{array}{l}\text { Hibicus rosa-sinensis } \mathrm{L} . \\
\text { merah }\end{array}$ & Malvaceae & bunga & merah muda - & - China & $\mathrm{S}$ & 2 \\
\hline $\begin{array}{l}\text { Homalomena pendula } \\
\text { (Blume) Bakh. F. }\end{array}$ & Araceae & getah & $\begin{array}{l}\text { merah } \\
\mathrm{Su}\end{array}$ & $\begin{array}{l}\text { Sulawesi, } \\
\text { umatra, India }\end{array}$ & P.H & 2 \\
\hline Impatiens platypetala Lindl. & Balsaminaceae & bunga & Merah muda & Jawa & $\mathrm{H}$ & 1 \\
\hline Indigofera scandens L. & Fabaceae & daun & hijau & Jawa & P.H & 5 \\
\hline Iresine herbstii Hook. & Amaranthaceae & daun & merah & Brazil & P.H & 3 \\
\hline Lavandula officinalis L. & Lamiaceae & bunga & Hitam & - & & 2 \\
\hline Leontodon autumnalis L. & Asteraceae & bunga & kuning & - & P.H & 3 \\
\hline Liquidambar formosana Hance. & Altingiaceae & batang & hitam & China & $\mathrm{T}$ & \\
\hline $\begin{array}{l}\text { Macropanax undulatus } \\
\text { (Wall.ex G. Don) Seem }\end{array}$ & Araliaceae & buah & hitam & Jawa & $\mathrm{T}$ & 2 \\
\hline $\begin{array}{l}\text { Magnolia montana (Blume) } \\
\text { Figlar dan Noot. }\end{array}$ & Magnoliaceae & batang & coklat & Jawa & $\mathrm{S} / \mathrm{T}$ & 2 \\
\hline Malvaviscus arboreus Cav. & Malvaceae & bunga & merah & Meksiko & $\mathrm{S}$ & 1 \\
\hline $\begin{array}{l}\text { Medinilla speciosa } \\
\text { (Reinw ex Blume) Blume }\end{array}$ & Melastomataceae & buah & Merah muda & Jawa & $\mathrm{S}$ & 1 \\
\hline Melastoma malabathricum L. & Melastomataceae & buah & ungu, merah & India & $\mathrm{S}$ & 2 \\
\hline $\begin{array}{l}\text { Mentha arvensis L. avanica } \\
\text { (Blume) Hook.f. }\end{array}$ & Lamiaceae & daun & coklat & Eropa & P.H & 1 \\
\hline $\begin{array}{l}\text { Muehlenbeckia platyclados } \\
\text { Meisn. }\end{array}$ & Polygonaceae & buah & ungu & Somolon & S.Cl & 4 \\
\hline Musa acuminata $\mathrm{L}$. & Musaceae & getah & coklat & Jawa & P.H & 3 \\
\hline $\begin{array}{l}\text { Odontosoria chinensis (L.) } \\
\text { J. Smith }\end{array}$ & Dennstaedtiaceae & daun & coklat & Jawa & P.Fn & 3 \\
\hline Pandanus amaryllifolius Roxb. & Pandanaceae & daun & hijau & Indonesia & $\mathrm{S}$ & 3 \\
\hline $\begin{array}{l}\text { Pandorea jasminoides (Lindl.) } \\
\text { K. Schum. }\end{array}$ & Bignoniaceae & bunga & merah muda & - & $\mathrm{S}$ & \\
\hline Pavetta montana Reinw. ex Blume & Rubiaceae & buah & hitam Ja & awa, Sumatra & $\mathrm{S} / \mathrm{T}$ & 2 \\
\hline Peristrophe bivalvis Merr. & Acanthaceae & daun & ungu & Jawa & $\mathrm{S}$ & 3 \\
\hline $\begin{array}{l}\text { Peristrophe hyssopifolia } \\
\text { (Burm.f.) Bremek. }\end{array}$ & Acanthaceae & bunga & ungu & Jawa & $\mathrm{S}$ & - \\
\hline $\begin{array}{l}\text { Photinia integrifolia var. } \\
\text { integrifolia Lindl. }\end{array}$ & Rosaceae & pucuk daun & merah & Sumatra & S & - \\
\hline Phyllanthus emblica L. & Phyllanthceae & kulit batang & $\begin{array}{r}\text { biru tua, Ja } \\
\text { merah, hitam }\end{array}$ & awa, Sumatra & $\mathrm{T}$ & - \\
\hline Pilea melastomoides (Poir.) B1. & Urticaceae & daun & hijau & Jawa & $\mathrm{H}$ & 3 \\
\hline $\begin{array}{l}\text { Pinanga coronata } \\
\text { (BlumeexMart.) Blume }\end{array}$ & Arecaceae & buah & Coklat-Hitam & $\begin{array}{l}\text { Jawa, } \\
\text { Sumatra }\end{array}$ & $\mathrm{T}$ & 3 \\
\hline Piper aduncum L. & Piperaceae & daun & hijau & Jawa & P.Cl & 1 \\
\hline Polygala venenosa Juss. ex. Poir. & Polygalaceae & bunga & ungu & Jawa & $\mathrm{S}$ & 2 \\
\hline Prunus arborea (Blume) Kalkman & Rosaceae & bunga & merah muda & Jawa & $\mathrm{T}$ & 2 \\
\hline Prunus cerasoides D. Don. & Rosaceae & bunga & merah muda & Himalaya & $\mathrm{T}$ & 2 \\
\hline Prunus costata (Hemsl.) Kalkman & Rosaceae & bunga & merah & Papua & $\mathrm{T}$ & 2 \\
\hline Psychotria angulata L. & Solanaceae & bunga & merah & & $\mathrm{S}$ & 2 \\
\hline Pterocarpus indicus L. & Fabaceae & kulit batang & merah & Jawa & $\mathrm{T}$ & - \\
\hline Rhodamnia cinerea Jack. & Myrtaceae & kulit buah & coklat & Jawa & $\mathrm{S} / \mathrm{T}$ & 2 \\
\hline $\begin{array}{l}\text { Rhodomyrtus tomentosa } \\
\text { (Aiton.) Hassk. }\end{array}$ & Myrtaceae & kayu & hitam & Asia & $\mathrm{T}$ & - \\
\hline Ricinus communis L. & Euphorbiaceae & daun dan buah & hitam & Jawa & $\mathrm{S}$ & 3 \\
\hline Rubus ellipticus Sm. & Rosaceae & daun & hijau & Himalaya & $\mathrm{S}$ & 2 \\
\hline Rubus fraxinifolius Poir. & Rosaceae & buah & jingga & Jawa & $\mathrm{S}$ & 2 \\
\hline Salvia ianthina Otto ex Dietr. & Laminaceae & bunga & coklat & Meksiko & P.H & 1 \\
\hline
\end{tabular}




\begin{tabular}{|c|c|c|c|c|c|c|c|}
\hline 94 & $\begin{array}{l}\text { Salvia splendens Sellow } \\
\text { ex wied-Neuw. }\end{array}$ & Laminaceae & bunga & ungu & Brazil & P.H & 3 \\
\hline 95 & Sinningia sellovii (Mart.) Wiehler & Gesneriaceae & bunga & merah & - & P.H & 2 \\
\hline 96 & Sophora tomentosa $\mathrm{L}$. & Fabaceae & daun & hijau & Sulawesi & $S$ & 3 \\
\hline 97 & Strobilanthes cernua Blume & Acanthaceae & daun & ungu & Jawa & P.H & 5 \\
\hline 98 & $\begin{array}{l}\text { Symplocos cochichinensis (Lour.) } \\
\text { S. Moore }\end{array}$ & Symplocaceae & buah, daun & Ungu, kuning & g Himalaya & $\mathrm{S} / \mathrm{T}$ & 2 \\
\hline 99 & $\begin{array}{l}\text { Symplocos costata (Blume) } \\
\text { Choisy. }\end{array}$ & Symplocaceae & buah & ungu & Jawa & $\mathrm{S} / \mathrm{T}$ & 2 \\
\hline 100 & Symplocos fasciculata Zoll. & Symplocaceae & kulit batang & merah & Jawa & $\mathrm{S} / \mathrm{T}$ & \\
\hline 101 & $\begin{array}{l}\text { Symplocos ludica (Thunb.) } \\
\text { Siebold dan Zucc. }\end{array}$ & Symplocaceae & buah & ungu & Jawa & $\mathrm{S} / \mathrm{T}$ & 2 \\
\hline 102 & $\begin{array}{l}\text { Symplocos odoratissima } \\
\text { Choisy. ex Zoll. }\end{array}$ & Symplocaceae & buah & ungu & Jawa & $\mathrm{S} / \mathrm{T}$ & 2 \\
\hline 103 & $\begin{array}{l}\text { Symplocos ribes Jungh. } \\
\text { dan de Vriese. }\end{array}$ & Symplocaceae & buah & ungu & Sumatra & $\mathrm{S} / \mathrm{T}$ & - \\
\hline 104 & Syzygium cumini (L.) Skeels. & Myrtaceae & batang & coklat & Jawa & $\mathrm{T}$ & 1 \\
\hline 105 & $\begin{array}{l}\text { Syzygium polyanthum } \\
\text { (Wight) Walp. }\end{array}$ & Myrtaceae & kulit batang & $\begin{array}{l}\text { hitam, coklat } \\
\text { merah }\end{array}$ & t, Sumatra & $\mathrm{T}$ & - \\
\hline 106 & Syzygium zeylanicum DC. & Myrtaceae & kulit buah & $\begin{aligned} & \text { hitam } \mathrm{Su} \\
& \mathrm{Su}\end{aligned}$ & $\begin{array}{l}\text { Sumatra, Jawa, } \\
\text { ulawesi, Papua }\end{array}$ & $\mathrm{T}$ & - \\
\hline 107 & Taraxacum officinale F.H. Wigg. & Asteraceae & bunga & kuning & - & $\mathrm{H}$ & 2 \\
\hline 108 & Tetranthera angulata (Blume) Nees. & Lauraceae & daun & merah & Jawa & $\mathrm{T}$ & 3 \\
\hline 109 & $\begin{array}{l}\text { Thunbergia mysorensis (Wight) } \\
\text { T. Anderson ex Bedd. }\end{array}$ & Acanthaceae & bunga & merah & Jawa & P.H & 3 \\
\hline 110 & Trema orientale (L.) Blume & Ulmaceae & kulit batang & coklat & Jawa & $\mathrm{T}$ & 2 \\
\hline 111 & $\begin{array}{l}\text { V. cylindricum Buch. Han } \\
\text { ex. D. Don }\end{array}$ & $\begin{array}{c}\text { Adoxiaceae/ } \\
\text { Caprifoliaceae }\end{array}$ & buah & hitam Ja & Jawa, Sumatra & $\mathrm{S}$ & 3 \\
\hline 112 & V. sambucinum Reinw ex. Blume & Adoxiaceae & buah & hitam & Jawa & $S$ & 3 \\
\hline 113 & Viburnum lutescent Blume & Adoxiaceae & buah & hitam & Jawa & $S$ & 3 \\
\hline 114 & Zingiber casumounarRoxb. & Zingiberaceae & umbi & kuning & Jawa & $\mathrm{P}$ & 2 \\
\hline 115 & $\begin{array}{l}\text { Zygocactus truncates (How) . } \\
\text { K. Scbum. }\end{array}$ & Cactaceae & bunga & ungu & - & $\mathrm{P}$ & 3 \\
\hline
\end{tabular}

Keterangan: T=Pohon; $\mathrm{S}=$ Semak; $\mathrm{S} / \mathrm{T}=$ semak atau kadang ditemukan dalam bentuk pohon; P.H=herba perennial; $\mathrm{P} . \mathrm{Cl}=$ perennial memanjat; $\mathrm{P}=$ Perennial; W.Cl=memanjat berkayu; $\mathrm{H} . \mathrm{Cl}=$ herba memanjat; $\mathrm{S} . \mathrm{Cl}=$ semak memanjat; $\mathrm{H}=$ herba $(-)=$ belum diketahui asal koleksinya/tidak diamati 